\title{
Introduction
}

\section{Economic Sociology: contributions for deconstructing market devices ${ }^{1}$}

\author{
Marina de Souza Sartore ${ }^{2}$ \\ Elaine da Silveira Leite ${ }^{3}$
}

Let's imagine two individuals searching for their soul mates on an online dating application. After the algorithmic process combines their personal profiles, they match, meet, fall in love and get married. After clearing their wedding party debts, they start to manage their household budget for furnishing the house with eco-certified wood, regularly buying organic food and hiring a medical home care professional for one of the grandparents. Sin-

1 We thank TOMO editorial committee for giving to us the opportunity to organize this special issue. We would also like to show our gratitude to Cae Rodrigues for reviewing this Introduction.

2 Department of Social Sciences and Postgraduate Program of Sociology, Federal University of Sergipe (UFS), Sergipe, Brazil. Markets and Organizations in Society Research Group (LEMOS).

3 Department of Social Sciences and Postgraduate Program of Sociology, Federal University of Pelotas (UFPel), Rio Grande do Sul, Brazil. New Sociologies (Economic, Financial and of Family) Research Group (GENS). 
ce they first met virtually, the next summer vacation destination will be chosen using TripAdvisor. Finally, to decide on savings and investments they agree to go to a promising, newly created bank from the merger between two large commercial banks, where some broker is unwilling to face the latest news about the lowering of Brazil's credit outlook due to uncertainties about the country's future economic scenario caused by the media during the last disputed presidential race.

The above narrative connects the articles in this special issue and illustrates that we are increasingly interacting and surrounded by market devices, accepting them as part of our everyday life: dating apps, household budgets, forest and food certifications, remuneration of medical home care professionals, online platforms for evaluating (travelling) experiences, artifacts guiding mergers and acquisitions, credit ratings and economic and political published prescriptions are all considered market devices that shape our contemporary collective economic life. The more we use them, the more they are taken for granted. When thinking about them, questions that come to mind are: "Is the algorithm/app capable of finding the best match?"; "What would be the best worksheet formula to manage my household budget?"; "Is certificated furniture and certificated food better?"; "What are the best forms of remuneration for home care professionals?"; "Are online travel platforms able to indicate the best tourist attractions?"; "Is the bank merger good or bad?"; "What should happen if Brazil's outlook is cut?"; "Are media analysts able to keep me informed about economic fluctuations?". We usually don't ask questions about the very existence of market devices; instead, the questions are related to how good or bad they are, how efficient, questions that are in harmony with our practical economic sense, i.e., with the economic doxa seen as a "set of fundamental beliefs that do not even need to explicitly assert themselves in the form of a self-conscious dogma" (BOURDIEU, 2001 / 1997a, p.25 [translated by the authors]). Since the economic doxa is deeply incorporated in our practical economic 
sense, we naturally frame our questions as normative (good or bad?) and prescriptive (what should I do and how should I do it?), questions that are deeply outlined by Economics.

Mainstream Economics became an autonomous research field, independent from other social sciences, by producing its own theories and methods for the explanation of economic phenomena (LOUREIRO, 1992; DEZALAY; GARTH, 2002; CANTU, 2008; BOURDIEU, 1997b; LEBARON, 2012). As medical doctors are able to correctly prescribe good treatments to each disease, Economists are able to prescribe good economic bailout programs for markets, fixing economic crises. As medical doctors, economists are usually faced with normative and prescriptive questions shaping the way we commonly approach markets devices: "Is this good?"; "Does it work?"; "What are the positive or negative impacts?".

In an analogy with 'old' vinyl records, if we only ask normative and prescriptive questions related to market devices, it would be like only playing and listening to the A-side of the record. Yet, to fully understand the composition of the album, we must also listen to the B-side, typically hidden while the A-side is playing. In this TOMO special issue, we invite the reader to listen to "the B-side of the record", bringing to light a more complete understanding of market devices through the "music" of Economic Sociology.

The main contribution of Economic Sociology is the use of sociological theories to explain economic phenomena (SWEDBERG, 2004), particularly markets (RAUD-MATTEDI, 2005). Most recently, social scientists have sought to overcome their own traditional researches on markets into a broader understanding that considers economic facts as products of social interactions (ABRAMOVAY, 2004), using sociology's analytical potentials to understand market devices in relation to the moral, political, and ethical-cultural aspects of Society. 
Let's go back to the protagonists portrayed in the opening paragraph of this introduction narrative. In addition to normative and prescriptive questions framing their objective and subjective thinking, the development of a framework using Economic Sociology to analyze market devices raises at least two new questions: the first is related to the genesis of market devices, e.g. "Where/How forest certifications were created and who was behind it?"; the second concerns the social operational logic of market devices, particularly in relation to other social phenomenon, e.g. "Do online dating platforms reproduce the practices of face-to-face dating?"; "Why does management of household budget generate so many money-making disputes between couples?"; "How does the relationship between intimacy and home care relate to the recognition of "caring' as a paid job?"; "Why do we believe in forest and food certifications?"; "Why did we replace printed guide books with online travel platforms?"; "How does the process for merger and acquisitions of companies in Brazil work on a daily basis?"; "Why are people afraid when an agency lowers Brazilian credit outlook?"; "How did economic newspaper prescriptions become trustworthy?". For the sociologically trained observer looking at market devices, social groups and social relations gain prominence in the task to recover both (a) the genesis of social phenomenon and (b) the social operational logic of market devices.

When it comes to recovering the genesis of social phenomenon, one seeks to understand both the moment before and after something was created, i.e. where were market devices created? Who was involved? What are the transformations they cause in the way society works? In this special issue, Marcelo Carneiro (The role of the prescription and judgment devices on the working of the markets: the forest certification case) and Paulo Nierdele and Guilherme Radomsky (Who rules by apparatuses? The production of norms and standards for organic food in Brazil) respectively demonstrate (a) the social groups involved in the creation of forest wood and organic food certificates and (b) the transfor- 
mations that occurred in society after their implementation: a "war of quality seals" in the forest certification market and a local counter-movement in the organic food market aiming to face dominant certification processes. The article written by Ana Carolina Bischoffe (Risk \& Control: Considerations on credit risk assessment devices and their implications for the standardization of Sovereign States and regulation of financial markets) reveals how the creation of the rating credit system shifts the power balance between private actors and State agencies in Brazil. Rodrigo Pires and Marcia Mazon (Work and intimacy: the professional constitution of caregivers in home care environment) reveal the tensions in the configuration of a new paying job situated at the frontier between the intimacy of private life and impersonal market work relations. The intention of these four articles is not to understand whether market devices have generated benefits or injuries, but rather how social groups that are mediated by power relations prompt the creation of new market devices and how these new devices ultimately change the way society works.

The sociological approach to the social operational logic of market devices considers these devices as analytical social spaces from where it is possible to apprehend and reveal both the form and content of social phenomena that shape our society. This is the case of the articles written by Elaine Leite, Gustavo Onto, Marina Sartore, Maria Jardim and Paulo Moura, and Karina Assis. Elaine Leite's starting point (From the device to the rationalities: the domestic and family budget in Brazil) is to demonstrate how household budgets reveal gender issues that shape daily household budget rationalities; Maria Jardim and Paulo Moura (The social construction of the social networking device market: the contribution of economic sociology to the applications of affective relationships) explore an online dating application to estimate the reproduction of face-to-face dating practices into the virtual world; Marina Sartore (TripAdvisor's Collective Representation on Beach Bars: the case of Aracaju-Sergipe) analyzes published written reviews on TripAdvisor to sketch out a Collective Re- 
presentation on beach bars located in the coastal city of Aracaju, Brazil; Gustavo Onto (Competition Devices: how and in what sense does antitrust policy makes markets) examines how the law regulating market competition is a device that outlines the content and the format for decision-making regarding mergers and acquisitions in Brazil; Karina Assis (Beyond rationality - the complexities inherent in the relationship among economics, politics and the media) emphasizes how economic thinking relies on dominant cognitive structures that take into account objective prescription devices shaping the ways of interpreting social reality.

Market devices and elements such as love, intimacy, leisure, and economic policy figure in this special issue disclosing a variety of theoretical and methodological paths that go beyond strictly normative and prescriptive analysis. Aiming to improve Brazilian empirical studies about market devices, Economic Sociology and its economic, cultural and moral aspects are brought forth to understand a changing and fluid social reality. Cardon (2015) argues that we are already living in a society imbued by algorithms. A peculiar characteristic of our time is not the fact that we classify, value and evaluate the social world, but rather the fact that we do it by using technological and virtual tools, most of them composed of algorithms capable of rapidly synthesizing, processing and disseminating big data in a way that have never been witnessed in our history: this new rapid and complex way of classifying generates new cognitive and cultural frameworks bringing into existence what Seyfert and Roberge (2016) call algorithmic cultures.

In the realm of the ordinary, the individual's daily life behold the effectiveness of indexes, budgets and norms which are believed to express the natural laws of Economics, seeing they are made up of algorithms and mathematical formulas. On the other hand, in the scientific realm, sociologists and economists historically created a division of labor (that echoes in Brazil) in which eco- 
nomists produce clean models and devices to read economic realities, while sociologists undertake the "dirty hands" analysis, going deeper to read these realities (HIRSCH; MICHAEL; FRIEDMAN, 1987). This division of labor demarcated the knowledge produced by each realm: Economists deal with normative and prescriptive analysis, while Sociologists handle the historical and logical de-reconstruction of market devices and their socially created realities.

Along with this labor division between Sociology and Economics, market devices play a double role: the first, close to Economics, sets in motion the expansion of markets, since they surpass the economic division of classes by diffusing numerous services and products to diverse sectors of the population. Nowadays, a variety of market devices are offered via online applications that are connected to financial networks targeting the sale of homes and properties, travels, consumer goods, etc. However, this market expansion is imbued with moral, cultural, political, and social values, transforming society cognitions, leading to the second role of market devices, close to Sociology, that recreates or reproduces forms of social stratification, making distinctions about food, love, intimacy, nature and so on. For example, the existence of certified forest wood furniture both expands the wood furniture to a new market niche and also stratifies the individuals into categories of responsible or irresponsible consumers.

To sum up, when Economists look at market devices, they follow different paths from those taken by Sociologists. We understand that the way we look at market devices is mainly outlined by Economics, having a direct influence on our economic doxa (BOURDIEU, 2001 / 1997a). On the other hand, Sociologists commit to providing theories and analytical tools to deconstruct this economic doxa, revealing the socially constructed logic behind it. The table below summarizes the A-side and the B-side of this record, i.e. the Economic and Sociological view on market de- 
vices. Together, they allow the reader to better understand the composition of markets and societies.

Table 01. Economic and Sociological Questions about Market Devices

\begin{tabular}{l|l}
\hline A-side - Economic Questions & B-side - Sociological Questions \\
\hline Prescriptive (How/What) & $\begin{array}{l}\text { Genesis (Who created and in what } \\
\text { conditions?) } \\
\text { How do they work (Which social reality } \\
\text { they reveal or alter?) }\end{array}$ \\
Normative (Negative and Positive) & $\begin{array}{l}\text { Market devices are socially constituted } \\
\text { subjective objects }\end{array}$ \\
\hline $\begin{array}{l}\text { Market devices are naturally consti- } \\
\text { tuted objective objects }\end{array}$ & Focus on social stratifications \\
\hline Focus on market expansion &
\end{tabular}

Source: Made by the authors.

Thus and so, far from incurring the dangers of dualities (ZELIZER, 2009) by accentuating the division of labor between these areas, the ambition of this special issue is to clarify the shadows, that is, to emphasize the importance of sociological knowledge in revealing social mechanisms that may potentially result in deconstructions of market devices. Here, Economic Sociology dialogues with other realms such as Sociology of Morality, Economic Anthropology, Sociology of Evaluation and Valuation, Political Sociology, inviting the reader to listen a bit closer to the B-side of the record.

\section{Exchanges with international theories}

Sociological explanations about economic phenomena can be traced back to Karl Marx, Emile Durkheim and Max Weber (RAUD-MATTEDI, 2005). However, it was only from the nineteen eighties on, especially with the publication of Mark Granovetter's article, "Economic action and social structure: the problem of Embeddedness" (1985), that sociology theories focusing on the study of economic phenomena duly unfolded. Later, Pierre 
Bourdieu's articles about the Economic Field (1997b) and the social structures of the economy (2000) motivated the growth of Economic Sociology in France. These two authors came to have great influence in Brazilian Economic Sociology, being the most cited authors in this field between 2000 and 2010 in Brazilian articles (JUNIOR, 2011). Brazilian Economic Sociologists, especially those with international exchanges, created a framework mixing national and international references to study markets devices.

Among the major objects studied by Economic Sociology are firms, organizations, institutions, markets, networks, labour markets, the State, money and other types of currencies. Especially from the nineteen eighties on, these research objects have been approached using anthropological perspectives, more specifically, cultural studies relating economic devices to intangible (and unpriced) things such as nature and intimacy. This quite unexpected encounter between markets, cultural and moral values brings about the quest for understanding how values and forms of evaluations establish or redefine markets. This substantial cultural turn assumes that markets are, themselves, cultures (FOURCADE; HEALEY, 2007), to the extent that market exchanges involve "more or less conscious efforts to categorize, normalize and naturalize behaviors and rules that are not natural in any way" (FOURCADE; HEALY, 2007, p. 300). These conscious efforts to categorize, normalize and naturalize behaviors are mediated by market devices.

The more recent focus on the forms of classification, valuation and evaluation has motivated Lamont (2012) and Cefaï et. al. (2015) to sketch a Sociology of Valuation and Evaluation by synthetizing and systematizing sociological studies centering on the forms of valuation and evaluation. In Brazil, the compilation of theories into a Sociology of Valuation and Evaluation is evolving, even if at a snail's pace. In 2013, Sartore and Leite (2013) organized a special issue on Economic Sociology and Sociology 
of Finance to emphasize the close dialogue between Sociology of Valuation and Evaluation and Economic Sociology; in this special issue, the organizers translated Lamont's article (2013) to Portuguese, bringing to the Brazilian public the international panorama of valuation and evaluation studies at that time. The major highlight was how the cultural turn and the rising influence of Sociology of Valuation and Evaluation on Brazilian Economic Sociology stirred apprehensions and reinterpretations of economic phenomena in Brazil, dialoguing mostly with French and North American ideas and concepts, as also evidenced by the articles published in this especial issue.

Gustavo Onto (Competition Devices: how and in what sense does antitrust policy makes markets) makes use of the idea that Economic Science is performative, i.e. it shapes and formats the economy (CALLON, 2007). He also uses the concept of devices, considered as "material and discursive assemblages that intervene in the construction of markets" (MUNIESA; MILLO; CALLON, 2007**4, p. 2). Devices are the way through which performative process occurs. Gustavo Onto examines antitrust policies practiced by the Administrative Council for Economic Defense (CADE) and considers them as competitive devices that "guide, conduct and determine behavior, discourses and ideologies in markets" (ONTO, in this special issue, p. 15). The dialogue with French theories is combined with the Ethnographic method to get hold of data on modern economic phenomena; this methodological approach to contemporary economic objects comes from projects developed by the Center for Research on Culture and Economy ${ }^{5}$ (NUCEC), from the National Museum at Rio de Janeiro (cf. NEIBURG, 2007**).

Ana Carolina Bischoffe (Risk \& Control: Considerations on credit risk assessment devices and their implications for the standardi-

4 The complete references cited with ${ }^{* *}$ can be found in the referred cited articles published in this special issue.

5 In Portuguese: Núcleo de Pesquisa em Cultura e Economia 
zation of Sovereign States and regulation of financial markets) undertakes documental and content analysis to assess the idea, inspired by Bourdieu (2014)** and Fourcade (2012)**, that market devices are forms of classifications that create economic realities. For her, Brazilian State's credit outlooks determined by rating agencies are performative (CALLON, 1998**; MACKENZIE, 2009**) and have the potential to modify the power monopoly traditionally held by the State over the production of classifications. In the pursuit of understanding State disputes over the power to classify, Ana Carolina Bischoffe takes into account the Sociology of Quantification (DESROSIÈRES, 2008**). The French analytical influence and methodological approach guide her quest for understanding the formation of tacit knowledge in markets; i.e. the practical economic reasoning that comes from cultural cognitive disputes; this approach is steadily in line with researches produced by the Economic Sociology and Sociology of Finance Study Center ${ }^{6}$ (NESEFI), from the Federal University of São Carlos (cf. GRÜN, 2008b**).

Also a researcher from NESEFI, Karina Assis presents an article (Beyond rationality - the complexities inherent in the relationship among economics, politics and the media), inspired by the French Economic Sociology that studies Media (BOLTANSKI, 1993**; BOURDIEU, $1983^{* *} ; 1997^{* *}$ ) to reveal the influence of the Economic Field (LEBARON, 2012**) over political disputes. She assumes that economic-financial prescription devices are products of cultural disputes between different conceptions about how to design Brazilian policies. She seeks to uncover the construction of economic-financial devices by analyzing Media articles, considering that the social positions of the agents, groups and institutions are determined by their dispositions (habitus) and their social positions (BOURDIEU, 1992**; 1983**). Her analysis of this cultural dispute is underpinned by the $2002 / 2003$ presidential race between PSDB's and PT's political parties, arguing that the 
Media had an important role in correlating catastrophic economic forecasts to the PT party based on the party's political positions.

Maria Jardim and Paulo Moura (The social construction of the social networking device market: the contribution of economic sociology to the applications of affective relationships) disagree with Illouz's (2011)** statement that virtual dating devices reinforce a rational economic behavior of finding a soul mate. This global trend to search goods and services using virtual applications fed by huge amounts of algorithmically processed data is studied locally by emphasizing two central ideas of Economic Sociology: (a) economic embeddedness, presented in works from Polanyi $(1980)^{* *}$ and Granovetter (2007)**, to address rational economic behaviors embedded in Society and (b) habitus orchestration (BOURDIEU, 2004**) to question the extent to which the virtual device recreates or reproduces habitus orchestrations produced in the "real" face-to-face world. The authors conducted interviews to understand the collective behavior of Tinder's local users, concluding that the collective virtual behavior is homologous to the collective real (physical) behavior in the social world. The search for understanding the ways dominant categories of economic thought are produced and legitimized can be found in the works from the Center for Studies and Research on Society, Power, Organization and Market $^{7}$ (NESPOM), from São Paulo State University - Araraquara. (cf. JARDIM, 2011).

Elaine Leite (From the device to the rationalities: the domestic and family budget in Brazil) dialogues with North American Economic Sociology (ZELIZER, 1994**). She considers the household budget as a calculative device that, despite being regarded by the dominant economic social imaginary as a technical artifact, also has a daily moral dimension associated with gender perceptions. Using literature review and focus-group interviews, she

7 In Portuguese: Núcleo de Estudos e Pesquisa sobre Sociedade, Poder, Organização e Mercado 
demonstrates the metamorphoses in ideas associated with household budgets, showing how this market device is filled up with moral judgments. The understanding of moral judgments inherent to modern economic phenomena is a strong feature of the New Sociologies (Economic, Financial and of Family) Research Group $^{8}$ - (GENS), from the Federal University of Pelotas (LEITE, $\left.2016^{* *} ; 2017^{* *}\right)$.

Paul Nierdele and Guilherme Radomsky (Who rules by apparatuses? The production of norms and standards for organic food in Brazil) bring together Boltanski and Thévenot's (1991)** ideas about Moral Policy, Foucault's (2008a)** concept of Governmentality and Fligstein's (1997)** incumbents and challengers' social skills in a given field to broach the subject of organic food certification in Rio Grande do Sul. They use literature review and field research to frame Brazilian rules and standards for organic foods as market devices through which power relations are at stake. There's a dominant group that dominates the organic certification's grammar and also a dominated group that seeks to modify this grammar by creating new alternative devices aiming to alter the balance of power. Paulo Nierdele, who participates in the Group for Studies in Family Agriculture and Rural Development $^{9}$ (GEPAD), from the Federal University of Rio Grande do Sul, joined Guilherme Radomsky to write for this special issue. Their partnership stems from their participation in both the Postgraduate Programs of Sociology and the Postgraduate Program of Rural Development, both located at the Federal University of Rio Grande do Sul, allowing them to contribute in a novel multidisciplinary approach to issues related to rural development and Sociology.

Marcelo Carneiro (The role of the prescription and judgment devices on the working of the markets: the forest certification case) 
presents two French Sociology ideas: first, he assumes that forest certification systems are prescription devices, since they are produced by experts defining the features, as well as the ways to make judgments about a product's quality (HATCHUEL, $2010^{* *}$ ). Second, he points out that forest certification systems are artifacts producing impersonal knowledge that is able to adjust consumer expectations with the offered product (KARPIK, $2007^{* *}$ ). He links Karpik's theoretical perspective with Garcia-Parpet's (2009)**, arguing that the role of prescription agents expresses power relationships - despite how the forest certification system seems to be neutral, a more careful analysis reveals that there is an inclination which favors "a determined forest company or a certain way for coordinating forestry activity" (CARNEIRO, in this special issue, p. 162). Carneiro's article dialogues with studies developed by the Work and Society Research and Study Group ${ }^{10}$, from the Federal University of Maranhão.

Marina Sartore (Tripadvisor's Collective Representation on Beach Bars: the case of Aracaju-Sergipe) apprehends the Collective Representation (DURKHEIM, 1898**) of Beach Bars in the city of Aracaju, Northeastern Brazil, from online written reviews on TripAdvisor. She stands for the scientific relevance of considering written reviews published in the platform as Collective Representations. The endeavor for understanding how calculative market devices, such as indexes, shape the construction of markets is one of the central issues from the Markets and Organizations in Society Research Group ${ }^{11}$ (LEMOS), from the Federal University of Sergipe (SARTORE, 2009).

Rodrigo Pires and Marcia Mazon (Work and intimacy: the professional constitution of caregivers in home care environment) are inspired by the work of Zelizer $(2010 \mathrm{~b})^{* *}$ to make sense of moral conflicts and tensions taking part in the consolidation of 
the home care profession in Florianópolis, city in the South of Brazil. They combine the case of Brazilian home care professionals with the theoretical perspective that markets are cultural complex political processes subjected to controversies. The search for understanding the moral setting of markets is an important feature of the Center for Economic Sociology ${ }^{12}$ (NUSEC), from the Federal University of Santa Catarina (UFSC). Rodrigo Pires, Professor at the Department of Public Health, joined Marcia Mazon, Professor at the Department of Social Sciences, both at UFSC, to compose this unique contribution by using Economic Sociology to study market regulations of professions that delve into life intimacy.

Existing market devices illustrate ways in which individuals symbolically establish close bonds and create networks among themselves and with institutions by sorting and assigning values and evaluations through various market devices, comprising the social world. Thus, when considering elements apparently set above markets' pricing process, such as nature, intimacy and pleasure, we epistemically change the ways we understand market devices, allowing us to recognize the social and arbitrary attributes and character of markets in order to contribute to a deeper awareness of how they begun and how they work. Even if our reader isn't familiar to the cited foreign theories, it is important to provide an overview of how they were appropriated and reinterpreted by Brazilian researchers. It is these tasks that this special issue wants to accomplish. Thus and so, we invite the reader to enter the world of Brazilian Economic Sociology and its theoretical and methodological intersections with national and international theories for unveiling market devices that permeate our daily lives. 


\section{Special Issue Structure}

The articles published at this special issue reveal new ways to analyze naturally embedded market devices in Brazilian society, bringing new explanations that go beyond the strictly normative and prescriptive analysis, calling out for new forms of valuation and evaluation that put in evidence social mechanisms that are behind the constitution and functioning of markets. Previously, we invited the reader to hear the B-side of the record. Yet, as we live now in the 21st century, we expect these two views (Economics and Sociology) to be presented in one compact disk, sharing the songs listened from an equal, visible, single side.

The three initial articles show the way to the far-reaching political world where market devices are found in political decisions on mergers and acquisitions, in credit ratings, as well as in Media economic prescriptions. The fourth and fifth articles takes the reader down to daily ordinary realities where devices appear in romantic and domestic investment decisions. The last four articles give impetus to the everyday world of consumption where market devices are transforming decisions about food, furniture, travel and care services. We wish you a fruitful reading!

\section{Ref erences}

ABRAMOVAY, R. Entre Deus e o Diabo - mercados e interação humana nas ciências sociais. Tempo Social, v.16, n.02, p.35-64, Nov.2004.

BOURDIEU, P. Meditações Pascalinas, 2001/1997a.

le champs économique. Actes de la recherche en Sciences Sociales, v. 119, n. 1, p. 48-66, 1997b.

P. Les Structures sociales de l'économie. Paris : Seuil, 2000.

CANTU, R. O campo dos pesquisadores em economia no Brasil no começo do século XXI. Anais do 32ํㅡㄹ Encontro Anual da ANPOCS, 2008. 
CARDON, D. À quoi rêvent les Algoritmes - Nos vies à l'heure des big data. Paris :Seuil, 2015.

CEFAI, D ; ZIMMERMANN, B ; NICOLAE, S ; ENDREB, M. Introduction. (Special Issue: on Sociology of Valuation and Evaluation). Hum. Stu, v. 38, n.01, Março, 2015.

DEZALAY, Y; GARTH, B. G. The internationalization of palace wars: lawyers, economists, and the contest to transform Latin American States. Chicago/ London: The University of Chicago Press, 2002.

FOURCADE, M; HEALY, K. Moral Views of Market Society. Annual Review of Sociology, v. 33, 2007.

GRANOVETTER, M. Economic action and social structure: the problem of Embeddedness. American Journal of Sociology, v.01, n. 03, p. 481-510, Nov 1985.

HIRSCH, P; MICHAELS, S; FRIEDMAN, R. 'Dirty hands' versus 'Clean Models': Is Sociology in Danger of Being Seduced by Economics? Theory and Society, v. 16, n.3, p. 317-336, 1987.

IARDIM, M. A. C. A natureza social das finanças: sindicalistas, fundos de pensão e remodelação das elites. Bauru: Edusc, 2011. 202p.

JUNIOR, E. Um balanço da sociologia econômica brasileira (2000-2010). XV Congresso Brasileiro de Sociologia, 26 a 29 de Julho, Curitiba, 2011.

LAMONT, M. Toward a Comparative Sociology of Valuation and Evaluation. Annual Review of Sociology, v. 38, p. 201-221, Agosto de 2012.

LAMONT, M. Para uma conexão necessária entre a Sociologia da Valoração e da Avaliação com a Sociologia Econômica e das Finanças (Tradução). NORUS, v. 1, p. I, 2013.

LEBARON, F. A formação dos economistas e a ordem simbólica mercantil. REDD - Revista Espaço de Diálogo e Desconexão, v.4, n.2, 2012.

LOUREIRO, M. R. Economistas e Elites Dirigentes no Brasil. Revista Brasileira de Ciências Sociais, v.7, n. 20, p.47-69, 1992.

RAUD-MATTEDI, C. A construção social do mercado em Durkheim e Weber: análise do papel das instituições na sociologia econômica clássica. RBCS, v.20, n. 57, fev. 2005.

SARTORE, M.S. An essay on Stock Markets Sustainability Index Committees. Society for the Advancement of Socio Economics - Conference proceedings. Paris, França, 2009. 
SARTORE, M. S.; LEITE, E. S. Introdução ao Dossiê. Sociologia Econômica e das Finanças: Perspectivas contemporâneas sobre a economia, as finanças e seus atores. Norus - Novos Rumos Sociológicos, v. 1, p. I-VII, 2013.

SEYFERT, R; ROBERGE, J. Algorithmic Cultures. Essays on Meaning, Performance and New Technologies. Nova Iorque: Taylor \&amp; Francis, 2016.

SWEDBERG, R. Sociologia Econômica: hoje e amanhã. Tempo Social. São Paulo: USP, v.16, n.02. 2004.

ZELIZER, V. Dualidades perigosas. Mana, v.15, n.1, p. 237-256, 2009. 